\title{
György Dragomán
}

\section{The Narrative Paradox}

\section{The virus of nothingness in Samuel Beckett's Watt}

Watt is not an easy novel to describe, summarise or paraphrase. According to Hugh Kenner this is so "since the style of Watt is the most efficient that can be discovered for expounding that kind of material Watt contains." ${ }^{1}$ The text intrudes into the mind of the reader forcing him to begin to think like Watt, in infinite series of permutations. Therefore, Kenner goes along in saying that "the analyst whose stock-in trade is his skill at putting his author's matter before his reader in pithier or less redundant language will find no purchase here." ${ }^{2}$ Form and content are not easily separated, each can and must be explained away in terms of the other, but the circularity of the argument will be closer to the insane attitude of endless investigation celebrated in the novel than to the ordinary world of logic and reason.

The novel consists of four parts and an Addenda, and describes Watt's quest, the long and tediou: journey he undertakes to arrive at Mr. Knott's country house where he will be one of an always arriving and departing series of servants, spending an undisclosed amount of time on the ground floor, after which he is on duty on the first floor for a time, until another servant arrives, and he is relieved and departs, back into the world from where he came.

The first and the last part describes Watt's arrival and departure, the second is dedicated to his stay on the ground floor and accordingly the third is about his time spent on the first floor. Each of the first three parts contains a longer passage

\footnotetext{
${ }^{1}$ Hugh Kenner. A Readers Guide to Samuel Beckett. London: Thames and Hudson, 1973, p. 76.

${ }^{2}$ Kenner. A Readers Guide to Samuel Beckett, p. 76.
} 
which is in no apparent relation to the story. In the first section we have the short statement of Arsene, Watt's predecessor, relating the story of his own stay in $\mathrm{Mr}$. Knott's house. The second part contains the genealogy of the wretched Lynch clan, a family of twenty-eight, which has the strange goal of achieving the collective age of a thousand years. In the third part Arthur, the next in line of the servants, tells the story of Mr. Ernest Louit's fraudulent investigations into "The Mathematical Intuitions of the Visicelts" which culminates in Louit's examination, conducted by a committee of five.

During his stay in Mr. Knott's house Watt undergoes a profound change. Though aided by logic he attempts to understand everything, he notices that he is unable to understand, much less to describe what is happening to him, and gradually loses control of his self, his language and his mind, not necessarily in this order. The motives of his quest are undisclosed, just as his background or his future. What exactly he looks for or finds in Mr. Knott's house is not known. What he will find he is unable to explain or understand, but he is just as unable to understand his own inability of understanding, so he is locked into a vicious circle, madly constructing useless explanations and intricate patterns which he then discards in favour of other patterns or explanations which he will discard once again, until gradually the very language will become a set of such useless explanations, something to be disposed of.

\section{THE PARADOX: "NOTHING WITH THE CLARITY OF SOMETHING"}

When he goes into Mr. Knott's house, Watt is actually on a quest. This might not be apparent at the very beginning, but Arsene, Watt's predecessor makes it clear towards the end of his monologue, when, preparing for departure, he gives Watt a final warning, which can be read as an encouragement:

And now for a little along the way that lies between you and me Erskine will go by your side, to be your guide, and then for the rest you will travel alone, or with only shades to keep you company, and that I think you will find, if your experience resembles mine, the best part of the outing or at least the least dull, even though the light falls fast, and far below the stumbling feet.

(Watt, p. 62) ${ }^{3}$

\footnotetext{
${ }^{3}$ All parenthesised references are to this edition: Samuel Beckett. Watt. London: Picador, 1988.
} 
This is a rather Dantesque goodbye, and also a reference to consolation Knowledge gives to Everyman. "Everyman, I will go with thee, and be thy guide. ${ }^{4}$ Erskine will turn out to be a sorry Virgil, and a rather peculiar kind of Knowledge, madly running around the corridors of the house, up and down the stairs, in infinite search of the elusive Mr. Knott. Arsene does not make a secret of the dangers of the journey: when one walks among the shades and the "light falls fast," the possibility of losing the right track and becoming a shade is a likely prospect. There are further suggestions in the novel which attest Watt's likely transformation into a shadow. The inquisitive Mr. Hackett begins the tirade of questions aimed at the discovery of Watt's past with the following unquestionable statement: "One does not part with five shillings to a shadow" (Watt, p. 19). Watt's changed attitude towards the sun also supports this possibility. At the beginning we find that "For if were two things that Watt disliked, one was the moon, and the other was the sur" (Watt, p. 31), but in the third part a footnote informs us about a change in this attitude: "Watt liked the sun at this time, or at least supported it. Nothing is known about this volte-face. He seemed pleased that all the shadows should move, not only himself" (Watt, p. 151). It is not clear whether Watt thinks about himself as a shadow at this time, but the suggestion is there.

Failure is a definite possibility, and if we take a look at the circumstances of Watt's arrival, when forty-eight pages before he was first hurled into the novel (by an angry tram conductor), we will see that he did not move, just lay there "on the pavement, motionless, a solitary figure, lit less and less by the receding lights, until it was scarcely to be distinguished from the dim wall behind it" (Watt, p. 14).

This does not seem to be a very promising start for a journey, and one is reminded of Mr. Belacqua Sloth, another of Watt's predecessors, the hero of More Pricks than Kicks, and another reference to Dante in his person, who bears the curse of constant laziness. Watt is not lazy, he is merely exhausted. For Belacqua the rest in the shade by the side of the road is permanent in the fourth Canto of Dante's Purgatory. Watt will get up, and leave the scene, but later on, he will yield to the temptation of the ditch once again, though not because of laziness but out of pure necessity.

But he had not continued very far when, feeling weak, he left the crown of the road and sat down on the path, which was high, and edged with

4 "Everyman." Everyman and Medieval Miracle Plays. Ed. A. C. Cavley, New York: E.P. Dutton, 1959. 
thick neglected grass. He knew, as he did so, that it would not be easy to get up again, as he must, and move on again as he must. But the feeling of weakness, which he had been experiencing, was such that he yielded to it.

(Watt, p. 31)

The feeling of weakness proves too strong for Watt, but he is constantly aware of the imperative nature of his journey. ${ }^{5} \mathrm{He}$ goes on because he cannot help going on. His attitude resembles that of the Unnamable, who utters those famous words at the end of the Trilogy: "where I am, I don't know, I'll never know, in the silence you don't know, you must go on, I can't go on, I'll go on."

Going along roads is a constant occupation for Beckett's heroes, slowly and taking great pains, suffering from every step, on crutches, in wheelchairs, on bicycles, but they will go along further and further till the very end. Watt gets up and continues, he will go on, never minding that his quest will turn out to be a failure, never minding the constant abuse he is subjected to, never minding the exhaustion and suffering. At the end of the novel we will see him lying on the floor of a waiting room, sleeping, but as soon as they wake him up (by emptying a slop bucket over him) he will get up, and will patiently ask for a ticket, at first only till the "nearer end" of the line, but then he changes his mind, and says that the ticket should be till "the farther end." Perhaps a mere slip of the tongue, but it could as well be the sign of a stubborn, invincible inclination. Watt does not despair, he has every reason why he should, but he does not. He goes on.

When in the Three Dialogues Beckett talks about the paintings of Tal Coat, he objects to the notion that Tal Coat or Matisse should be called revolutionaries, because he feels that they only managed to disturb "a certain order on the plane of the feasible." When he is asked to elaborate what other plane there should be, he answers that although logically there could be none, the true artist has no choice but to turn away from it all the same being "weary of its puny exploits, weary of pretending to be able, of being able, of doing little better the same old thing, of going a little further along a dreary road." Asked what remains to such an artist, a despairing and proud Beckett asserted that "[t]he expression that there is nothing to

\footnotetext{
${ }^{5}$ Upon first seeing him, Mr. Hackett gives an intuitive rendering of Watt's attitude to his journey: "The thought of leaving town was most painful to him, $[\ldots]$ but the thought of not doing so no less so. So he sets off for the station, half hoping he may miss his train. [...] Too fearful to assume himself the onus of decision, [...] he refers it to the frigid machinery of time-space relation" (Watt, p. 19).

${ }^{6}$ Samuel Beckett. Trilogy. London: Picador, 1979, p. 382.
} 
express, no power to express, no desire to express, together with the obligation to express." Watt cannot help going along on the "dreary road." But once he arrives in Mr. Knott's house he will have an ample share of the nothingness to be experienced, expressed and understood.

Like that of Godot, Watt's and Mr. Knott's names provoke interpretation and lead critics into wondering about the nature of whatness and notness. Watt's name is seen like a question, ${ }^{8}$ Mr. Knott's as a negative answer. ${ }^{9}$ Watt is the inquisitive probing force of discovery, $\mathrm{Mr}$. Knott is notness incarnate, wrapped in a neat parcel tied up with a Gordian knot. ${ }^{10}$ "Change all the names" reads one entry of the Addenda. But just as in Godot's case, the names are specially well chosen. Watt is on a quest, and he fails, perhaps because Mr. Knott is not called Mr. Kyess.

Watt's problems begin with the first "fugitive intrusion" into Mr. Knott's house, the arrival of Galls "father and son." The two gentlemen have come "all the way from town" to "choon the piano" which task they dutifully attempt to accomplish, ${ }^{11}$ and then depart. For Watt this becomes an episode of extreme importance, though he is not able to grasp the reason of its importance. His ordinary perception is changed and he is forced to look for meaning in the occurrence:

\footnotetext{
${ }^{7}$ Samuel Beckett. Disjecta. New York: Grove Press, 1984, p. 139.

${ }^{8}$ Two interesting examples for interpreting Watt's name: Hugh Kenner suggests that if the book is really indebted to the theories of Ludwig Wittgenstein, then the protagonist's name is in fact nothing but a compromise "between What and Witt" (Hugh Kenner. Samuel Beckett: a Critical Study. New York: Grove Press, 1961, p. 58). According to John Pilling, "One of the gestalt psychologists Külpe, had an assistant named Watt whose discoveries suggested that our behaviour is so conditioned by our original intention that any secondary elements that are part of our consciousness are effectively without content" (John Pilling. Samuel Beckett. London, Henely and Boston: Routledge and Kegan Paul, 1976, p. 130). Watt is a good choice for a name because it encourages a wide range of interpretations.

9 John Butler Lance links Mr Knott to Heidegger: "Heidegger asks if anyone has looked into the ontology of 'notness,' and here surely is Watt attempting it in his speculations about Mr 'Knott.' Even before he has come properly face to face with Mr Knott, Watt's narration (or Sam's or Beckett's) is stiff with the word 'not'" (St. John Butler Lance. Samuel Beckett and The Meaning of Being, A Study in Ontological Parable. London: Macmillan Press, 1984, p. 47).

${ }^{10}$ One example of this kind of interpretation: "[The novel] answers the question 'What?' by 'Not!' as Watt, for unknowable reasons, enters the service of Mr. Knott" (Francis Doherty. Samuel Beckett. London: Hutchinson and Co., 1971, p. 19).

${ }^{11}$ Here we have another failure - while the piano is in a rather grave condition as "The mice have returned [...] Nine dampers remain [...] and an equal number of hammers [corresponding only in one case] [...] the strings are in flitters." The Galls do not fail to draw the consequence: "The piano is doomed [...] the piano-tuner also [...] the pianist also" (Watt, p. 69). It seems that they not only recognise their own failure, but on this basis they also revert to the liberty of prophesising doom.
} 
Yes, Watt could not accept [...] that nothing had happened, with all the clarity and solidity of something, and that it revisited him in such a way that he was forced to submit to it all over again, to hear the same sounds, see the same lights, touch the same surfaces, as when they had first involved him in their unintelligible intricacies.

(Watt, p. 73)

Watt is unable to understand or explain, because nothing is not something to be explained and understood. It is a negative, which cannot even be defined, as it negates understanding, and is incomprehensible. It should be dismissed. Watt feels this need, and strives for the possibility of dismissal, but the vision of nothing is visited on him, and he has no choice but to attempt to understand it. But understanding only works within the realm of logic, and Mr. Knott's premises seem to transcend those boundaries.

Steven J. Rosen sees Watt's attitude as a "hostility to meaning" and he writes that the narrator "describes a discovery of meaninglessness, or nothing." ${ }^{12}$ Rosen is mislead by the general and shallow nature of the term "nothing," and immediately associates meaninglessness with it. Watt's problem is the contrary, he would easily dismiss a meaningless nothing, but he happened to have the misfortune of stumbling upon a meaningful nothing, which is almost a something, and accordingly, he is convinced that there is a meaning, but he is unable to find out just what exactly that meaning could be.

Watt's experiences might prove to be unimportant, might be dismissible, rejecting them would be an easy solution of the problem, but Watt would rather "turn the other cheek" than turn away. Watt suspects the existence of a meaning, and he needs an explanation regarding the nature of that meaning. Any explanation would do, but an explanation is definitely needed. "Watt could not accept them for what they were, the simple games that time plays with space, now with these toys, and now with those" (Watt, p. 73). Seeing "nothing" might be the mystical experience in search of which Murphy ties himself into the rocking chair, but Watt is not Murphy and "because of his peculiar character," he will not be able to realise that he is elevated from the "plain of the feasible" and continues walking on the road till the very end, failure or no failure.

12 Steven J. Rosen. Samuel Beckett and the Pessimistic Tradition. New Brunswick, New Jersey: Rutgers UP, 1976, p. 62. 
Watt believes that Nothing is something which should not be seen, a transcendence, and once he has seen it, he is helplessly locked in the paradox, oscillating from nothing back to something, and from something back to nothing, without end. ${ }^{13}$ This oscillation is present in the novel well before Watt's confrontation with nothing. The way he enters Mr. Knott's house is one of the best examples in this respect:

The house was in darkness. Finding the front door locked, Watt went to the back door. [...] Finding the back door locked also, Watt returned to the front door. Finding the front door locked still, Watt returned to the back door. Finding the back door now open, [...] Watt was able to enter the house.

(Watt, pp. 34-35)

One may wonder after how many attempts would Watt finally have given up. How the door was opened will never be known, neither by Watt, nor by anybody else, turning it into one of the few miraculous and undisclosed secrets of the book. Watt is prone to oscillation, ${ }^{14}$ and this attitude will lock him into the paradox.

Faced with nothing, the only possible solution would be an explanation, a way "to elicit something from nothing" (Watt, p. 76) because for Watt "to explain" always means "to exorcise" and sadly enough this is the only thing which carries such a meaning, and accordingly, when Watt is unable to explain, he is unable to exorcise, and when he is unable to exorcise, he is possessed, possessed by nothing. ${ }^{15}$

Watt is in a loophole, enclosed by his own stubborn inclination to understand. It seems that there is no way out, yet his situation is not entirely without hope (after all, he managed to get into the house) and the chance for failure is always a possibility.

\footnotetext{
${ }^{13}$ Hans Joachim Schulz links this Beckettian paradox to Hegel's paradoxical conclusion expounded in Wissenschaft der Logic: "The positive and the negative are identical - A simple reflection?' Much of rhythm of the Beckett novels is that of the movement of the negative into the positive (and vice versa)" (Hans-Joachim Schulz. This Hell of Stories: A Hegelian Approach to the Novels of Samuel Beckett. The Hague, Paris: Mouton, 1973, p. 13).

${ }^{14}$ Though he seems to understand its futility. When on the station he sees the porter wheeling milkcans up and down the platform, there and back again his reaction is the following: "He is sorting the cans, said Watt. Or perhaps it is a punishment for disobedience or some neglect of duty" (Watt, p. 24). This remark evokes the image of Sisyphus, which is immediately blended with the slapstick of the situation, producing a sample of the sinister humour of the novel.

15 The catatonic Mr. Endon, whom we encounter in Murpiry, is such a character, he is entirely possessed by nothing, he is "within" for good and all, he does not communicate with the outer world as he has nothing to communicate, or the nothing he has cannot be communicated.
} 
Watt learned towards the end of his stay in Mr. Knott's house to accept that nothing had happened, that a nothing had happened, learned to bear it even, in a shy way, to like it. But then it was too late.

(Watt, p. 77)

By the end of his stay, Watt will fail, and be victorious in his failure, presenting a compromise, managing, in a way, and against all odds to "elicit something from nothing."

\section{SPEAKING ABOUT THE UNSPEAKABLE: COMMUNICATION AND NARRATION}

Logic and logical methods, or at least the know-how of a logical approach are burnt into Watt's brain, and he will utilise it, for attempting to create formulations of his experiences, and if necessary, to repair the subsequent "cracks" in the resulting formulation. ${ }^{16}$ Of course a paradox defies formulation, the two conflicting statements cancel each other out, Arsene's speech is full of mystical sentences like "Everything that happened happened inside it, and at the same time everything that happened happened outside it" (Watt, p. 42), but for Watt accepting such nonsense will not be possible until the very end of his stay in $\mathrm{Mr}$. Knott's house.

Watt's mechanical struggle with Nothing conveys an air of the slapstick, but his mundane and mechanical methods are efficient in their inefficient way. His problem is the basic Beckettian problem of seeing the unseeable, knowing the unknowable, and speaking about the unspeakable, and his partial success ${ }^{17}$ in these grave endeavours will prove that this is in some ways possible. "But to elicit something from nothing requires a certain skill and Watt was not always successful, in his efforts to do so. Not that he was unsuccessful either, for was not" (Watt, p. 74).

\footnotetext{
${ }^{16}$ At this point, the underlying grim humour of the issue must be stressed. What follows is very close to a philosophical argument - when analysing Watt's problem and solution, we will be touching issues of epistemology and ontology, and utilising parallels found in philosophical thought is a tempting possibility (cf. St. John Butler Lance, p. 122), but our aim in reconstructing Watt's system of thought lies only in the devastatingly damaging and humorous consequences all this will have on the structure of fiction, that is, in the novel.

${ }^{17}$ The consequences of a total failure are reckoned with: "No he [Watt] could never have spoken at all of these things, if all had continuer to mean nothing, as some continued to mean nothing, that is to say, right up to the end" (Watt, p. 74). And, accordingly, Watt will not be able to give Sam any examples of this kind.
} 
His method is what Vivian Mercier calls the "the philosophic equivalent of sleight of hand or rule of thumb." 18

For the only way one can speak of nothing is to speak of it as though it were something, just as the only way one can speak of God is to speak of him as though he were a man, which to be sure he was, in a sense, for a time, and as the only way one can speak of man, even our anthropologists have realized that, is to speak of him as though he were a termite.

(Watt, p. 74)

This kind of success will have severe consequences (besides permanently degrading man to the level of a termite), as the structure of "ordinary" somethings will also be impregnated by nothing, and the uncertainty of information, the unreliability and difficulty of communication typical of this kind of discourse will be manifest virtually everywhere, as there will be no way of differentiating between something and nothing. Most of Watt's problems, his paranoid uncertainty, or the breakdown of naming and language he will experience, originate from this uniformity.

Murphy, Beckett's previous novel, begins with a curious sentence, which seems to affirm the cyclical repetitive routine of time, flatly denying the possibility of change. "The sun shone, having no alternative, on the nothing new." ${ }^{19}$ At the end of the first part of Watt, we find a sentence which asserts the opposite: "[A]ll the gold and white and blue would fill the kitchen, all the unsoiled light of the new day, of the new day at last, the day without precedent at last" (Watt, p. 63). Contrasting these two sentences is a lucrative way for pointing out the basic underlying difference between the two novels. It seems that the "nothing new" can turn into a "day without precedent," the fixed circle of predestination can somehow be broken.

Murphy wa: beset with his own paradox, and communication between him and Mr. Endon was not possible. The game of chess broke down, Mr. Endon would stick to his secret, undisclosed set of rules, in vain did Murphy offer his pieces for sacrifice, the repetitive ritual guaranteeing that Mr. Endon's pieces would get back into their starting position could not be broken, and the only thing Murphy could glimpse in the black of Mr. Endon's pupils was the reflection of his own self. Mr. Endon was the world within, and Murphy was the world without and they were hopelessly and absolutely separated.

\footnotetext{
${ }^{18}$ Vivian Mercier. Beckett/Beckett. New York: Oxford UP, 1977, p. 167.

${ }^{19}$ Samuel Beckett. Murphy. London: Picador, 1973, p. 5.
} 
Just like Murphy and Mr. Endon, Watt and Sam (another "meaningful" name) also meet in some sort of an asylum, but here holes can be found in the intricate system of barbed-wire fences, and a communication between Watt and Sam is possible. ${ }^{20}$ What is more, this communication turns out to be crucial with regards to the novel, as we graduaily find out that in fact Sam is the narrator, or at least one of the narrators.

Information is problematic, this is made clear at the very beginning. Arsene describes the story of his meeting with a gentleman, who makes a big effort and produces his watch (casting down a great many layers of clothing, just like Mr. Knott will do later on), to tell the time which according to him is "seventeen minutes past five exactly, as God is my witness. ${ }^{21}$ Arsene does not always finish the stories embedded in his monologue, but this time he gives us the punchline, followed by the consequences the issue implies for him: "A moment later Big Ben (is that the name?) struck six. This in my opinion is the type of all information whatsoever, be it voluntary or solicited" (Watt, p. 44). We may notice how uncertainty intrudes into Arsene's speech at this very moment, as demonstrated by the question in the parentheses. But this is just half of the problem. The receiving end in the communication is beset by impatience, indifference and misunderstanding. Watt does not pay attention to Mr. Spiro, to Arsene, to Erskine or to anyone else.

Sam, on the other hand, is (or at least seems to be) a good listener. After all, he manages to patch together Watt's story, though he is careful to provide a detailed list of the difficulties involved in the process. Time is the first deterring factor: "When Watt at least spoke of this time it was a time long past, and of which his recollections were [...] less clear than he would have wished." This is followed by the imperfect nature of human memory: "Add to this the notorious difficulty of recapturing at will, modes of feeling peculiar to a certain time, and to a certain place." The third problem is presented by speech itself: "Add to this the obscurity of Watt's communications, the rapidity of his utterance and the eccentricities of his syntax, as elsewhere recorded." External conditions are also far from ideal: "Add to this the material conditions in which these communications were made." And, as the story has to be retold by Sam, all of

\footnotetext{
${ }^{20}$ Some critics (cf. St. John Butler Lance, p. 25) see this as an advance, but it may well be a mere consequence of a shift in focus, which does not justify any kind of value judgement.

${ }^{21}$ We should bear in mind the policeman's answer to a similar claim made by Mr. Hackett: "God is a witness that cannot be sworn" (Watt, p. 6).
} 
these problems occur once again: "Add to this the scant aptitude to give of him to whom they were committed" (Watt, pp. 71-72).

Narration is problematic, and what is more, the narrator is aware of the problematic nature of narration. After listing the problems, he finishes with a disclaimer, which can be read as a warning:

some idea will perhaps be obtained of the difficulties experienced in formulating [...] the entire body of Watt's experience, from the moment of his entering Mr. Knott's establishment to the moment of his leaving it.

(Watt, pp. 71-72)

Here the narrator steps in the light, attracting a great deal of critical attention, but most critics will find that the narrative structure of the book cannot be convincingly accounted for on the basis of the quasi "ignorant" or "unreliable" narrator model, as presented by Sam.

Abbot $\mathrm{H}$. Porter is puzzled by the fact that contrary to this disclaimer the narrator talks about things which Watt could never have told him. "There are things narrated which Watt could never have told Sam. So round it goes, like the voices in Watt's head - we are never sure whether they are coming from the inside or from the outside., ${ }^{22}$

David Watson explains the "narrational unreliability" of the text as the consequence of a "fundamental problematisation of the very notion of subjectivity" and argues against the presence of an "ignorant narrator" on the grounds that "the degree and nature of the narrator's ignorance and 'amnesia' quite literally defy belief" in addition to which the text "often employs discursive forms of knowledge which are totally incongruous with the notion of a literally 'ignorant' narrator - in some ways the narrator's problem lies in knowing too much.".

Vivian Mercier sees Watt as a transition between the omniscient narrator utilised in Murphy, and the first-person narrator employed in the Trilogy. Accordingly, he believes that the book still suffers form the presence of such an omniscient narrator. ${ }^{24}$

It seems that the narrator is not omniscient, yet he is not ignorant either. Omniscience disowns the existence of nothing. As soon as ordinary reality is tainted

\footnotetext{
${ }^{22}$ H. Abbott Porter. The Fiction of Samuel Beckett: Form and Effect. Berkeley, Los Angeles, London: University of California Press, 1973, pp. 64-65.

${ }^{23}$ David Watson. Paradox and Desire in Samuel Beckett's Fiction. London: Macmillan, 1991, pp. 11-12.

${ }^{24}$ Vivian Mercier, p. 9.
} 
by nothing, omniscience is no longer a possibility. The first part, or rather the first half of the first part, up to Arsene's monologue, is constructed on an omniscient basis, indeed it does not differ in a great deal from Murphy. Footnotes are present, commenting on the text. But the omniscience is broken as soon as Watt arrives into Mr. Knott's premises, because neither Watt nor the reader will ever find out, exactly how Watt managed to get into Mr. Knott's house.

Omniscience is broken; Watt's suffering cannot possibly be described in such a way. Arsene's monologue which concludes the chapter is followed by Sam's, but this shift in narration is not disclosed until quite some time later, till the appearance of the Galls and the emergence of nothing forces the narrator to make the cited disclaimer, and, as a consequence, to reveal himself. Sam's monologue attempts to faithfully reconstruct Watt's battle against nothing, yet his comments on and interpretations of Watt's story will uphold the attitude of the omniscient narrator, without the actual omniscience. For Sam maintaining the air of omniscience is not difficult, because Watt in all his struggle and suffering thrives for a form of omniscience, an explanation which would account for the totality of the world he experiences.

Sam's contract only lasts for the time Watt spends in Mr. Knott's house (he makes this clear at the point he emerges), that is, the second and the third part of the novel. In the last part the omniscient narrator of the first part will return, but the battered mask of omniscience can no longer be convincingly upheld, more and more hiatuses appear in the manuscript. Watt's own incapability of omniscience shatters the possibility of omniscience for good and all, and the novel concludes in a total breakdown of the forms of fiction: the Addenda, the fragments of which according to a footnote were not incorporated in the novel because of "fatigue, and disgust" (Watt, p. 247). Here the bones of the novel are laid bare, showing how the actual construction is done, shattering the last illusion of omnipotence.

Sam's narration is framed by the narrative of the unnamed narrator of the first and last part, and the footnote-comments constitute a frame which contains the whole of this embedded structure. This feature gives the book a formal unity, and at the same time manages to destroy the very last hope of such formal homogeneity. Most of the footnotes aim to clarify some issue of the text, but the often insanely parodistic manner of these intended clarifications just manage to make the matters worse. In this respect they resemble Watt's constant explanations, which become more and more complicated and redundant, without any increase in their usefulness, as the basic irrationality they attempt to explain defies explanation as 
such. The footnotes ridicule the essence of the editorial approach, and make fun of the very notion that such violent intrusions into the structure of the novel would be able to clarify the contents and amend to the inherent chaos which reigns within. ${ }^{25}$

The insecure nature of the text also intrudes into the footnotes in other ways, not merely the parody. One of the footnotes may be cited as a fitting example. The story of the Lynch family includes a complicated set of calculations. These are preceded by the following footnote: "The figures here are incorrect. The consequent calculations are therefore doubly erroneous" (Watt, p. 101). And indeed, if one adds up the ages of the members of the family, the result will be nine hundred and seventy eight instead of the nine hundred and eighty reported in the text. The figures are incorrect, indeed, two years are missing. This mistake is noticed by Hugh Kenner, he sees this as a justification for the presence of the footnote, and a reference to non-Euclidean geometry. ${ }^{26}$

Before the footnote in the general list, Liz, Sam's wife is listed as "Liz née Sharpe aged thirty-eight years" (Watt, p. 99). She is the first to die and the loss of her passing is described in the following way: "This was a great loss to the family Lynch, this loss of a woman of forty good-looking years" (Watt, p. 102). The footnote was right, the numbers (or rather Liz's age as given before the footnote) were incorrect. This accounts for the missing two years, and the validity for the first half of the footnote.

But in the "consequent calculations" which come after the footnote, the mistake is corrected, and indeed if we manage to follow the syntax of the calculations, ${ }^{27}$ we may find that far from being "doubly erroneous" they are in fact meticulously correct. This proves the second half of the footnote to be "erroneous." Anyway, how can anything be doubly erroneous? Or is this to be interpreted as a negation of a negation which is in fact an affirmation, referring in an obscure way to the fact that the calculations are not erroneous at all? Patricia Waugh believes the footnote, she writes that "even if the figures were not in some epistemological

\footnotetext{
${ }^{25}$ At this point a comparison to Flann O'Brien is inevitable. In The Third Policeman footnotes are utilised in a strikingly similar manner. At some points the novel behaves as a biography of the mad scientist De Selby, and three different commentators of his work are permanently referred to in the footnotes.

${ }^{26}$ Hugh Kenner. A Readers Guide to Samuel Beckett, p. 79.

${ }^{27}$ The sentence: "Till changing in twenty over twenty-eight equals five over seven times twelve equals sixty over seven equals eight months and a half approximately, if none died, if none were born, a thousand years!" (Watt, p. 101) can be deciphered in the following way: $(20 / 28=5 / 7) \times 12=60 / 7=8.5$ approximately, the correct sum being just over 8.571428 .
} 
doubt, the reader's attention has anyway been called to the ontological status of the fictional text." ${ }^{28}$ Beckett's tricky use of the double error manages to undermine the ontological status of the text and the footnote alike. Both are wrong, both are correct, neither is wrong, neither is correct.

Watt is unable to come to terms with nothing; this will affect his story, which is the story Sam tells, which constitutes the two middle parts of the novel. Watt's ignorance affects the whole of the novel. The different layers of narration behave in a transparent manner, and the paradoxical nothing constituting the core of the novel has a radiating power which shines through all these layers, and accordingly, each layer is influenced by the others, ignorance may aspire for the pretension of omnipotence, and the complex nature of existence may turn omnipotence into impotence.

Vivian Mercier quotes an interview, where Beckett compares himself to Joyce saying:

This kind of work I do is one in which I'm not master of my material.

The more Joyce knew the more he could. He's tending toward omniscience and omnipotence as an artist. I'm working with impotence, ignorance. I don't think impotence has been exploited in the past. ${ }^{29}$

Watt is perhaps the first of Beckett's writings where ignorance and impotence are handled in such a way that the consequences of these issues are addressed in their totality. In Murphy the chaos of existence led to Murphy's death, but the structure and form of the novel was not affected by it. In Watt the paradox of something coexisting with nothing behaves like a virus, an infection which alters reality, influencing the form and structure of the novel in a devastatingly radical fashion.

\footnotetext{
${ }^{28}$ Patricia Waugh. Metafiction: The Theory and Practice of Self -Conscious Fiction. London, New York: Routledge, 1984, p. 44.

${ }^{29}$ Israel Shenker. "Moody Man of Letters." New York Times, $6^{\text {th }}$ May 1956, sec. 2. p. 3, quoted in Vivian Mercier, p. 8.
} 